\title{
Ammonia metabolism in chronic obstructive pulmonary disease with special reference to congestive right ventricular failure
}

\author{
A. VALERO, G. ALROY, B. EISENKRAFT, \\ and J. I T S KOVI T CH ${ }^{1}$ \\ Medical Department B, the Cardio-respiratory Laboratory, the Chemical Laboratory, \\ Rambam University Hospital and Aba Khoushy School of Medicine, Haifa
}

\begin{abstract}
Valero, A., Atroy, G., Eisenkraft, B., and Itskovitch, J. (1974). Thorax, 29, 703-709. Ammonia metabolism in chronic obstructive pulmonary disease with special reference to congestive right ventricular failure. A study of 36 patients was undertaken to evaluate the role of raised blood and CSF ammonia in the production of central nervous manifestations in chronic obstructive pulmonary disease (COPD) with special reference to congestive right ventricular failure (CRVF).

The patient material comprised five categories: 11 controls, seven mentally alert patients with COPD, eight with COPD and CRVF, four with primary cardiac disease and CRVF, and eight with cirrhosis of the liver. Each patient was examined clinically especially for neurological manifestations such as asterixis, confusion, and drowsiness. Each patient also had measurement of venous pressure, bromsulphthalein, ECG, chest radiograph, and spirometry.

The mean values of CSF-glutamine, $\mathrm{CSF}$ and arterial blood-ammonia, $\mathrm{pH}, \mathrm{PCO}_{2}$, and $\mathrm{PO}_{2}$ for each group were compared and statistically analysed. The results indicate that no correlation existed between central nervous manifestations acid-base balance or $\mathrm{PO}_{2}$. Ammonia-glutamine levels were found to relate to hepatic congestion whether it was caused by primary cardiac or pulmonary heart disease.
\end{abstract}

Central nervous system manifestations such as asterixis, irritability, confusion, hypersomnia or coma are not uncommon in chronic obstructive pulmonary disease (COPD). There is disagreement in the literature as to its aetiology, being variously ascribed to hypoxia, acidosis or hyperammonaemia (Dutton, Nicholas, Fisher, and Renzetti, 1959; Merwarth, Sieker, and Manfredi, 1961; Dulfano and Ishikawa, 1965; Posner, Swanson, and Plum, 1965; Posner and Plum, 1967; Szam, Vass, and Wein, 1969).

In a previous work (Valero, Alroy and Stein, 1971) we found that respiratory failure encephalopathy did not correlate well with acid-base disturbances of either blood or cerebrospinal fluid nor with blood and CSF $\mathrm{Po}_{2}$. We found, on the other hand, that CSF glutamine was significantly raised in COPD patients who had typical central

'Parts of this work were carried out by J. Itskovitch and will be presented at the Hebrew University Medical School in Jerusalem as a thesis for his M.D. nervous manifestations. Suspicion was raised that the changes were due to congestive heart failure but the direct relationship between raised CSF glutamine levels and the congestive livers could not be demonstrated since no blood ammonia determinations were carried out. Determination of blood ammonia was all the more important since experimental work has demonstrated increased contents of brain ammonia (Agrest, Bercovich, and Navon, 1965) and glutamine (Jaikin and Agrest, 1969) in rats exposed only to long-term hypercapnia.

The purpose of the present study was to evaluate more carefully the role of hepatic congestion in raising blood ammonia in COPD patients and its possible correlation with acid-base balance, $\mathrm{PaO}_{2}$, and CSF glutamine.

\section{MATERIAL AND METHODS}

The clinical material comprised 36 carefully assessed patients. Each had a complete clinical examination 
including direct measurements of venous pressure, bromsulphthalein (BSP) retention, chest radiography, ECG, and spirometry using a dry spirometer (Vitalograph Ltd., Buckingham, England).

In each case CSF-glutamine, -ammonia, -pH, -Pco:, and $\mathrm{PO}_{2}$ were determined concomitantly with arterialammonia, $-\mathrm{pH},-\mathrm{PCO}_{2}$, and $\mathrm{PO}_{2}$. Ammonia was also determined in venous blood. Oxygen therapy when applied was discontinued one hour before the abovenamed diagnostic procedures. Informed consent to carry out lumbar and arterial punctures was obtained in all patients.

A comparative study of these parameters was made in the following group divisions:

1. Eleven fully conscious controls who had lumbar punctures performed on them for signs of meningeal irritation in short-term pyrexias or for signs of mild cerebrovascular accidents. In this group informed consent was obtained for the arterial punctures.

2. Seven fully conscious and mentally alert patients with COPD due to chronic bronchitis and emphysema but with no signs of chronic congestive right ventricular failure (CRVF). The diagnosis was based on a typical history of winter or morning cough and wheezing respiratory rhonchi on examining the chest. Typical obstructive ventilatory studies corroborated the diagnosis.

3. Eight patients suffering from COPD (as above) but with obvious signs of CRVF, all with asterixis and varying degrees of hypersomnia, mental confusion, and drowsiness.

4. Four patients suffering from primary cardiac disease with definite CRVF. The aetiological background was ischaemic heart disease in two, and rheumatic heart disease involving the mitral and tricuspid valves in the remaining two.

5. Eight patients suffering from liver cirrhosis (except for one who was in acute yellow atrophy due to viral hepatitis). Cirrhosis was diagnosed by the presence of hepatosplenomegaly, spider angiomata, oesophageal varices, deranged liver function, and, in some, by needle biopsy.

The following neurological manifestations were sought in each patient: asterixis-defined as a flapping tremor consisting of jerky flexion and extension at the wrists while the arms are outstretched; hypersomnia-indicated by excessive sleepiness during day-time; signs of confusion disturbances of orientation and inability to count numbers backwards; drowsiness-a combination of hypersomnia and mental confusion; coma-where the patient could not be awakened even by painful stimuli.

All blood samples were obtained in fasting patients from an indwelling Cournand needle in the brachial artery. Blood was drawn anaerobically into a Luerlock syringe, heparinized and prepared with silicone. Lumbar punctures were carried out with patients lying on their sides. CSF was withdrawn slowly and anaerobically simultaneously with sampling of the brachial blood. The first few drops of fluid were used to wash out the syringe dead-space through a three-way stop- $\frac{\mathscr{\rho}}{0}$ cock. All blood and CSF samples were kept on ice and $\frac{C}{0}$ examined within 15 minutes.

\section{ANALYSIS}

A modification (Brandstaetter and Barzilai, 1960) of कै the Whitehead and Whittaker (1955) chemical method $\vec{\circ}$ was used for the determination of glutamine in the $\overrightarrow{\vec{H}}$ CSF. Blood and CSF ammonia were estimated by the $\omega$ procedure described by Seligson and Seligson (1951). $\stackrel{F}{\rightleftharpoons}$ This method, perhaps less suitable than the Seligson $\vec{x}$ and Hirahara (1957) method for ammonia blood esti- î mation, is certainly suitable for low protein fluid like ơ CSF. pH was measured anaerobically at $37.7^{\circ} \mathrm{C}$ in a capillary microelectrode (type AME, 1b, Radiometer $\mathrm{c}$ Corp., Copenhagen) standardized with the precision $ᄋ$ buffers at pH 6.840 and 7.381 before each reading. Duplicate readings were required to agree within $0.005 \bar{z}$ $\mathrm{pH}$ units. $\mathrm{PCO}_{2}$ was calculated by the micro-equilibration technique described by Siggaard-Andersen, Engel, $\Phi$ Jørgensen, and Astrup (1960). The pK for the CSF 항 was taken as 6.13 (Mitchell, Herbert, and Carman, ำ $1965)$. $\mathrm{PO}_{2}$ was measured with a Clark type electrode $\vec{\theta}$ (Radiometer).

\section{RESULTS}

A summary of the pertinent clinical and laboratory findings in the five patient categories is given in Table I.

The mean and \pm SD values are given in Table II, and levels of statistical significance in Tables III to $\mathrm{V}$.

AMMONIA In the control group, the ammonia values in arterial blood had a mean and \pm SD of $67 \cdot 0 \pm 21 \cdot 5 \mu \mathrm{g} / 100 \mathrm{ml}$. Since it is known that levels $\underset{\chi}{\tilde{\vartheta}}$ of venous ammonia change with muscular activity we have limited our statistical comparison to 3 . arterial ammonia. The normal average reported $\delta$ arterial ammonia is approximately $100 \mu \mathrm{g} / 100 \mathrm{ml}$ for the same method of examination (Seligson 을 and Seligson, 1951).

CSF ammonia determinations gave the lowest $\frac{D}{0}$ figures and the smallest scatter about the mean, probably because of the low CSF protein content. O

The mean ammonia levels of blood and CSF in N patients with COPD and no CRVF were not N different from the normal controls. Patients with COPD +CRVF, and patients with heart disease and CRVF had mean values which were all significantly higher than the mean of the control and $\stackrel{\mathscr{f}}{?}$ COPD no CRVF groups. The only exception was 0 that no significant statistical difference was found between blood ammonia levels of the COPD with $\overrightarrow{\mathbb{Q}}$ and without CRVF although such difference did $\underset{\mathbb{D}}{\stackrel{P}{~}}$ occur in the ammonia CSF means. This discrep- 
T A B L E I SUMMARY OF CLINICAL FINDINGS, MEAN VENOUS PRESSURES, AND BSP RETENTION

\begin{tabular}{|c|c|c|c|c|c|c|c|c|c|c|}
\hline \multirow[t]{2}{*}{ Category } & \multicolumn{2}{|c|}{ Age (yr) } & \multirow[t]{2}{*}{$\begin{array}{c}\text { Liver } \\
\text { Enlargement }\end{array}$} & \multirow[t]{2}{*}{$\begin{array}{l}\text { Pitting } \\
\text { Oedema }\end{array}$} & \multirow[t]{2}{*}{$\begin{array}{l}\text { Mental } \\
\text { State }\end{array}$} & \multirow[t]{2}{*}{ Asterixis } & \multicolumn{2}{|c|}{$\begin{array}{l}\text { Venous Pressure } \\
(\mathrm{cmH}, \mathrm{O})\end{array}$} & \multicolumn{2}{|c|}{$\underset{\%}{\text { BSP Retention }}$} \\
\hline & Range & Mean & & & & & Range & Mean & Range & Mean \\
\hline 1 Control & $15-69$ & 36 & - & - & Normal & - & $4 \cdot 0-7.0$ & $4 \cdot 3$ & $2 \cdot 3-3 \cdot 0$ & $2 \cdot 8$ \\
\hline no & $60-80$ & 69 & - & One & Normal & $2 / 7$ & $6 \cdot 0-14 \cdot 5$ & $9 \cdot 8$ & $2.6-5.0$ & $3 \cdot 8$ \\
\hline 3 COPD & $49-79$ & 63 & All & All & $\begin{array}{l}\text { Hypersomnic } \\
\text { or drowsy }\end{array}$ & All & $10 \cdot 0-18 \cdot 0$ & 15.0 & $3 \cdot 7-17 \cdot 0$ & $10 \cdot 3$ \\
\hline 4 Heart disease & $60-69$ & 64 & All & All & Normal & $2 \cdot 4$ & $16 \cdot 0-22 \cdot 5$ & $19 \cdot 7$ & $24 \cdot 0-27 \cdot 0$ & 25.5 \\
\hline 5 Cirrhosis & $19-67$ & 38 & All & - & $\begin{array}{l}\text { Drowsy } \\
\text { to coma } \\
\text { except } 2\end{array}$ & All & $4.0-6.0$ & 5.5 & $2 \cdot 8-23 \cdot 4$ & 13.4 \\
\hline
\end{tabular}

T A B L E I I

SUMMARY OF MEAN VALUES OF AMMONIA, ACID BASE BALANCE, $P \mathrm{O}_{2}$ IN CSF VENOUS AND ARTERIAL BLOOD AS WELL AS CSF GLUTAMINE

\begin{tabular}{|c|c|c|c|c|c|c|c|c|c|c|c|}
\hline \multirow{2}{*}{\multicolumn{2}{|c|}{ Category }} & \multicolumn{3}{|c|}{$\underset{(\mu \mathrm{g} / 100 \mathrm{ml})}{\text { Ammonia }}$} & \multirow{3}{*}{$\begin{array}{c}\begin{array}{c}\text { Glutamine } \\
\text { CSF } \\
\text { (mg/100 ml) }\end{array} \\
11 \\
7 \cdot 18 \\
2.09\end{array}$} & \multicolumn{3}{|c|}{ Arterial Blood } & \multicolumn{3}{|c|}{ CSF } \\
\hline & & \multirow{2}{*}{$\begin{array}{c}\text { Arterial } \\
11 \\
67 \cdot 00 \\
21.55\end{array}$} & \multirow{2}{*}{$\begin{array}{c}\text { Venous } \\
11 \\
67 \cdot 82 \\
25.61\end{array}$} & \multirow{2}{*}{$\begin{array}{c}\text { CSF } \\
11 \\
30 \cdot 18 \\
15 \cdot 50\end{array}$} & & \multirow{2}{*}{$\begin{array}{c}\text { pH } \\
11 \\
7.411 \\
0.036\end{array}$} & \multirow{2}{*}{$\begin{array}{c}\begin{array}{c}\mathrm{PCO}_{2} \\
(\mathrm{mmHg})\end{array} \\
11 \\
38.55 \\
3.98\end{array}$} & \multirow{2}{*}{$\begin{array}{c}\begin{array}{c}\mathrm{Po}_{\mathrm{g}} \\
(\mathrm{mmH})\end{array} \\
11 \\
94.63 \\
11.22\end{array}$} & \multirow{2}{*}{$\begin{array}{c}\mathrm{pH} \\
\begin{array}{c}11 \\
7.317 \\
0.031\end{array}\end{array}$} & \multirow{2}{*}{$\begin{array}{c}\begin{array}{c}\mathrm{PCO}_{2} \\
(\mathrm{mmHg})\end{array} \\
11 \\
48 \cdot 55 \\
5.85\end{array}$} & \multirow{2}{*}{$\begin{array}{c}\begin{array}{c}\mathrm{PO}_{2} \\
\text { (mmHg) }\end{array} \\
11 \\
40 \cdot 18 \\
6.85\end{array}$} \\
\hline Control & $\begin{array}{l}\text { n } \\
\text { Mean } \\
\text { SD }\end{array}$ & & & & & & & & & & \\
\hline $\begin{array}{c}\text { COPD } \\
\text { no } \\
\text { CRVF }\end{array}$ & $\begin{array}{l}\text { n } \\
\text { Mean } \\
\text { SD }\end{array}$ & $\begin{array}{c}6 \\
68 \cdot 17 \\
26 \cdot 20\end{array}$ & $\begin{array}{c}7 \\
54 \cdot 43 \\
11 \cdot 33\end{array}$ & $\begin{array}{c}7 \\
27 \cdot 43 \\
13 \cdot 79\end{array}$ & $\begin{array}{c}7 \\
8 \cdot 0 \\
1 \cdot 91\end{array}$ & $\begin{array}{c}7 \\
7 \cdot 381 \\
0 \cdot 043\end{array}$ & $\begin{array}{c}7 \\
46 \cdot 93 \\
13 \cdot 59\end{array}$ & $\begin{array}{r}7 \\
61 \cdot 57 \\
8 \cdot 40\end{array}$ & $\begin{array}{c}7 \\
7 \cdot 322 \\
0 \cdot 049\end{array}$ & $\begin{array}{c}7 \\
53 \cdot 36 \\
16 \cdot 17\end{array}$ & $\begin{array}{c}7 \\
43.0 \\
9.97\end{array}$ \\
\hline $\begin{array}{l}\text { COPD+ } \\
\text { CRVF }\end{array}$ & $\begin{array}{l}\text { n } \\
\text { SDean }\end{array}$ & $\begin{array}{r}7 \\
118 \cdot 17 \\
72 \cdot 93\end{array}$ & $\begin{array}{c}8 \\
147 \cdot 83 \\
88 \cdot 43\end{array}$ & $\begin{array}{c}7 \\
84 \cdot 57 \\
47 \cdot 19\end{array}$ & $\begin{array}{c}8 \\
13 \cdot 25 \\
5 \cdot 34\end{array}$ & $\begin{array}{c}8 \\
7 \cdot 355 \\
0 \cdot 062\end{array}$ & $\begin{array}{c}8 \\
59.00 \\
15.96\end{array}$ & $\begin{array}{c}8 \\
55 \cdot 13 \\
9 \cdot 67\end{array}$ & $\begin{array}{c}7 \\
7 \cdot 254 \\
0 \cdot 072\end{array}$ & $\begin{array}{c}\stackrel{7}{7}^{66 \cdot 29} \\
25 \cdot 36\end{array}$ & $\begin{array}{c}7 \\
44 \cdot 14 \\
7 \cdot 47\end{array}$ \\
\hline $\begin{array}{l}\text { Cardiac } \\
\text { with } \\
\text { CRVF }\end{array}$ & $\begin{array}{l}\mathbf{n} \\
\text { Mean }\end{array}$ & $\begin{array}{r}4 \\
171.00 \\
74.08\end{array}$ & $\begin{array}{r}4 \\
180 \cdot 75 \\
86 \cdot 26\end{array}$ & $\begin{array}{r}4 \\
120 \cdot 75 \\
50.68\end{array}$ & $\begin{array}{r}4 \\
13 \cdot 25 \\
4 \cdot 11\end{array}$ & $\begin{array}{c}4 \\
7.467 \\
0.038\end{array}$ & $\begin{array}{r}4 \\
28 \cdot 75 \\
1 \cdot 26\end{array}$ & $\begin{array}{r}4 \\
83 \cdot 25 \\
6 \cdot 13\end{array}$ & $\begin{array}{c}4 \\
7 \cdot 340 \\
0 \cdot 004\end{array}$ & $\begin{array}{c}4 \\
40 \cdot 25 \\
4 \cdot 19\end{array}$ & $\begin{array}{c}4 \\
34 \cdot 00 \\
4.55\end{array}$ \\
\hline $\begin{array}{l}\text { Hepatic } \\
\text { encephalopathy }\end{array}$ & $\begin{array}{l}\mathbf{n} \\
\text { Mean } \\
\text { SD }\end{array}$ & $\begin{array}{r}6 \\
211 \cdot 00 \\
76.48\end{array}$ & $\begin{array}{r}6 \\
177 \cdot 00 \\
55 \cdot 59\end{array}$ & $\begin{array}{c}6 \\
143.66 \\
83.74\end{array}$ & $\begin{array}{c}6 \\
36 \cdot 16 \\
22 \cdot 99\end{array}$ & $\begin{array}{c}5 \\
7 \cdot 460 \\
0 \cdot 067\end{array}$ & $\begin{array}{r}4 \\
28 \cdot 50 \\
5 \cdot 74\end{array}$ & $\begin{array}{c}4 \\
92 \cdot 50 \\
13 \cdot 43\end{array}$ & $\begin{array}{c}5 \\
7 \cdot 427 \\
0 \cdot 064\end{array}$ & $\begin{array}{c}4 \\
34 \cdot 25 \\
10 \cdot 53\end{array}$ & $\begin{array}{c}4 \\
46 \cdot 00 \\
12 \cdot 99\end{array}$ \\
\hline
\end{tabular}

T A B L E I I I

STATISTICAL COMPARISON OF SIGNIFICANCE LEVELS OF AMMONIA AND GLUTAMINE IN CONTROL, COPD NO CRVF, COPD + CRVF, AND HEART DISEASE WITH CRVF

\begin{tabular}{|c|c|c|c|c|}
\hline & & $\begin{array}{c}\text { COPD no } \\
\text { CRVF }\end{array}$ & $\begin{array}{l}\text { COPD } \\
+ \text { +CRVF }\end{array}$ & $\begin{array}{l}\text { Heart Disease } \\
\text { +CRVF }\end{array}$ \\
\hline $\begin{array}{r}\text { Ammonia } \\
\text { Arterial }\end{array}$ & $\begin{array}{l}\text { Control } \\
\text { COPD no } \\
\text { CRVF } \\
\text { COPD } \\
\text { +CRVF }\end{array}$ & $\begin{array}{l}\text { NS } \\
- \\
-\end{array}$ & $\begin{array}{c}0.02<P<0.05 \\
\text { NS } \\
-\end{array}$ & $\begin{array}{c}P<0.001 \\
P<0.02 \\
\text { NS }\end{array}$ \\
\hline CSF & $\begin{array}{l}\text { Control } \\
\text { COPD no } \\
\text { CRVF } \\
\text { COPD } \\
\text { +CRVF }\end{array}$ & $\begin{array}{l}\text { NS } \\
- \\
-\end{array}$ & $\begin{array}{l}P<0.01 \\
P<0.01 \\
-\end{array}$ & $\begin{array}{c}P<0.001 \\
P<0.001 \\
\text { NS }\end{array}$ \\
\hline Glutamine & $\begin{array}{l}\text { Control } \\
\text { COPD no } \\
\text { CRVF } \\
\text { COPD } \\
\text { +CRVF }\end{array}$ & $\begin{array}{l}\text { NS } \\
- \\
-\end{array}$ & $\begin{array}{l}P<0.01 \\
P<0.05 \\
-\end{array}$ & $\begin{array}{c}P<0.002 \\
P<0.02 \\
\text { NS }\end{array}$ \\
\hline
\end{tabular}


T A B LE I V

STATISTICAL COMPARISON OF SIGNIFICANCE LEVELS OF PaO, PaCo, AND pH IN CONTROL, COPD NO CRVF, COPD+CRVF AND HEART DISEASE WITH CRVF

\begin{tabular}{|c|c|c|c|c|}
\hline & & $\begin{array}{l}\text { COPD no } \\
\text { CRVF }\end{array}$ & $\begin{array}{l}\text { COPD } \\
+ \text { CRVF }\end{array}$ & $\begin{array}{l}\text { Heart Disease } \\
\text { +CRVF }\end{array}$ \\
\hline $\mathrm{PaO}_{2}$ & $\begin{array}{l}\text { Control } \\
\text { COPD no } \\
\text { CRVF } \\
\text { COPD } \\
\text { +CRVF }\end{array}$ & $\begin{array}{r}P<0.001 \\
- \\
-\end{array}$ & $\begin{array}{c}\text { P<0.001 } \\
\text { NS } \\
-\end{array}$ & 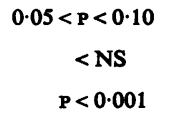 \\
\hline $\mathrm{PaCO}_{2}$ & $\begin{array}{l}\text { Control } \\
\text { COPD no } \\
\text { CRVF } \\
\text { COPD } \\
\text { +CRVF }\end{array}$ & $\begin{array}{l}0.05<P<0.10 \\
- \\
-\end{array}$ & $\begin{array}{c}P<0.001 \\
\text { NS } \\
-\end{array}$ & $\begin{array}{l}P<0.001 \\
P<0.001 \\
P<0.001\end{array}$ \\
\hline pH & $\begin{array}{l}\text { Control } \\
\text { COPD no } \\
\text { CRVF } \\
\text { COPD } \\
+ \text { CRVF }\end{array}$ & $\begin{array}{l}\text { NS } \\
- \\
-\end{array}$ & $\begin{array}{c}P<0.05 \\
\text { NS } \\
-\end{array}$ & $\begin{array}{l}P<0.05 \\
P<0.01 \\
P<0.01\end{array}$ \\
\hline
\end{tabular}

T A B L E V

STATISTICAL COMPARISON OF SIGNIFICANCE LEVELS OF Pcsfo, PcsfCO, AND pHcsf IN CONTROL, COPD NO CRVF, COPD + CRVF, AND HEART DISEASE WITH CRVF

\begin{tabular}{|c|c|c|c|c|}
\hline & & $\begin{array}{c}\text { COPD no } \\
\text { CRVF }\end{array}$ & $\begin{array}{c}\text { COPD } \\
+ \text { CRVF }\end{array}$ & $\begin{array}{l}\text { Heart Disease } \\
\text { +CRVF }\end{array}$ \\
\hline Pcsfo $_{2}$ & $\begin{array}{l}\text { Control } \\
\text { COPD no } \\
\text { CRVF } \\
\text { COPD } \\
+ \text { CRVF }\end{array}$ & $\begin{array}{l}\text { NS } \\
-\end{array}$ & $\begin{array}{l}\mathbf{N S} \\
\mathbf{N S} \\
-\end{array}$ & $\begin{array}{c}\text { NS } \\
\text { NS } \\
\text { P }<0.05\end{array}$ \\
\hline $\mathrm{PcsfCO}_{2}$ & $\begin{array}{l}\text { Control } \\
\text { COPD no } \\
\text { CRVF } \\
\text { COPD } \\
\text { + CRVF }\end{array}$ & $\frac{\text { NS }}{-}$ & $\begin{array}{c}P<0.05 \\
\quad \text { SS } \\
-\end{array}$ & $\begin{array}{l}\mathrm{P}<0.01 \\
\mathrm{P}<0.01 \\
\mathrm{P}<0.001\end{array}$ \\
\hline pHesf & $\begin{array}{l}\text { Control } \\
\text { COPD no } \\
\text { CRVF } \\
\text { COPD } \\
\text { +CRVF }\end{array}$ & $\begin{array}{l}\text { NS } \\
- \\
-\end{array}$ & $\begin{array}{l}P<0.02 \\
0.05<P<0,10 \\
-\end{array}$ & $\begin{array}{c}\text { NS } \\
\text { NS } \\
\text { P }<0.01\end{array}$ \\
\hline
\end{tabular}

ancy would appear to be due to the wide range of blood ammonia values.

GLUTAMINE The CSF glutamine differences in the various groups paralleled those of ammonia. The mean values were identical for the two CRVF groups and significantly higher than the means of the control and COPD no CRVF groups.

$\mathrm{PCO}_{2}$ VAlues Arterial $\mathrm{PCO}_{2}$ mean values in patients with COPD, COPD +CRVF, and heart disease with CRVF were not statistically different but each one was statistically different from the control mean.

pH values No significant difference was found between the $\mathrm{pH}$ mean values of the control group and that of the COPD group. Neither was there any difference between patients with COPD and COPD + CRVF. All other mean pH values were significantly different from one another. CSF pH was markedly constant except for an acidosis in $\underset{x}{\stackrel{0}{2}}$ the COPD +CRVF group which was significantly $\frac{0}{0}$ different from all other groups.

$\mathrm{PCO}_{2}$ VAlues Arterial $\mathrm{PCO}_{2}$ mean values in $\stackrel{\circ}{3}$ patients with COPD, COPD+CRVF, and heart $O$ disease with CRVF were all significantly different from the mean control. However, there was no significant difference between COPD and COPD + CRVF groups. In patients with heart disease and $\mathcal{N}$ CRVF the $\mathrm{PCO}_{2}$ means were significantly lower N than $\mathrm{PCO}_{2}$ means of either COPD or COPD + N CRVF groups. Statistically no difference was found between the mean values of the control or COPD groups on the one hand and the COPD + CRVF group on the other.

\section{COMMENT}

It is obvious that CSF ammonia and glutamine levels are a function of ammonia in arterial blood $\stackrel{\mathbb{D}}{\mathbb{D}}$ (Fig. 1). This does not agree with views expressed 


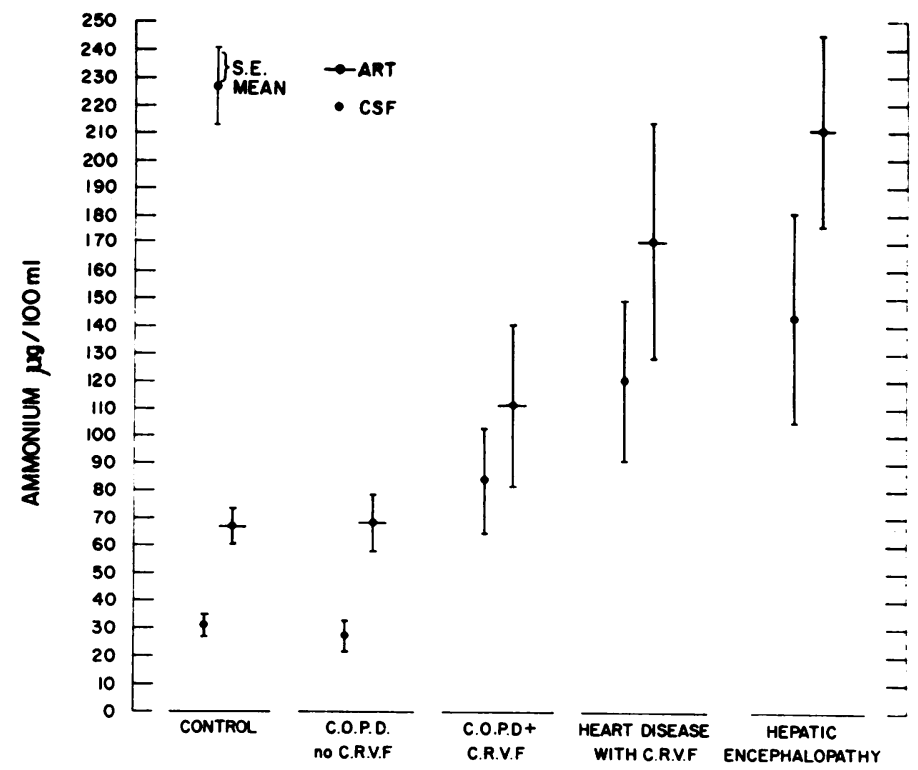

FIG. 1. Mean values ( $\pm S E$ ) of ammonia in blood and CSF in controls, patients with chronic obstructive pulmonary disease without right ventricular failure (COPD no CRVF) and with right ventricular failure $(C O P D+C R V F)$, heart disease with $C R V F$, and hepatic encephalopathy.

by Agrest et al. (1965) and Jaikin and Agrest (1969), who claimed that CSF glutamine is raised in the experimental animal and in patients as a result of increased central nervous system production of ammonia in hypercapnia. Our results show no such correlation between $\mathrm{PCO}_{2}$ and ammonia-glutamine in the CSF and anyway the correlation between ammonia and glutamine is well known (Krebs, 1935; Kaplansky and Berezovskaya, 1956). Also we could not demonstrate any correlation between hyperammonaemia and acidosis or hypoxia in the blood or CSF. Outstanding in this respect are the heart disease and CRVF patients who were markedly hyperammonaemic, hypocapnic, alkalotic, and hardly or only mildly hypoxic.

The only additional parameter which was common to the hyperammonaemic patients and did not exist in the patients who had normal ammonia values is liver congestion (Fig. 2). Our results, therefore, confirm those of Bessman and Evans (1955), who reported elevated blood ammonia levels in congestive heart failure. We conclude, therefore, that hyperammonaemia in our patients was related only to congestive right ventricular failure irrespective of its aetiology.

It is interesting to observe that blood and CSF ammonia levels, though lower in patients with congested livers, were comparable with those seen in patients with encephalopathy due to grave primary liver disease (Table II).

In our previous work (Valero et al., 1971) we did find a correlation between CSF glutamine and CNS manifestations such as asterixis and mental changes. It did not appear from our data that the mental state in respiratory insufficiency was dependent on CSF pH or $\mathrm{PCO}_{2}$ and it would seem from our present study that CSF $\mathrm{PO}_{2}$ is also not an aetiologic factor. The difficulty in assessing quantitatively CNS manifestations is obvious. A further objective correlative study between graded nervous changes and hyperammonaemia is necessary. We find it hard to explain the generally known fact that CNS manifestations are commoner in COPD patients than in patients with primary heart disease even when congestive right ventricular failure is prominent.

Our present work lacks also follow-up ammonia determinations in patients undergoing therapy, be it simple diuresis and digitalis or treatment aimed at reduction of ammonia formation, such as low protein diet and neomycin medication. Such a study is being carried out, using the more expedient ion exchange method for the determination of ammonia (Miller and Rice, 1963). 


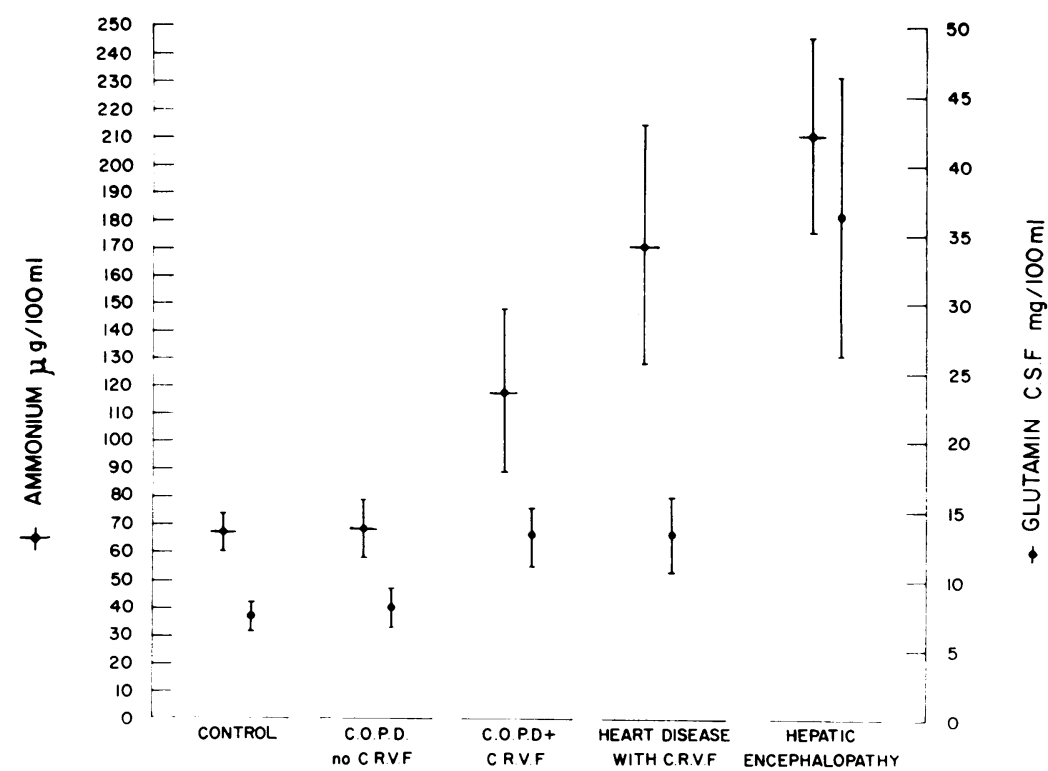

FIG. 2. Mean values ( $\pm S E$ ) of blood ammonia and CSF glutamine in controls, patients with chronic obstructive pulmonary disease without right ventricular failure (COPD no CRVF) and with right ventricular failure (COPD+ $C R V F)$, heart disease with $C R V F$, and hepatic encephalopathy.

\section{REFERENCES}

Agrest, A., Bercovich, C. De., and Navon, S. (1965). Ammonia and adenosine triphosphate in the central nervous system of rats with dyspnoea and chronic hypercapnia. Clinical Science, 28, 401.

Bessman, A. N. and Evans, J. M. (1955). The blood ammonia in congestive heart failure. American Heart Journal, 50, 715.

Brandstaetter, S. and Barzilai, D. (1960). Glutamine estimation in CSF in liver disease. American Journal of Digestive Diseases, 5, 945.

Dulfano, M. J. and Ishikawa, S. (1965). Hypercapnia; mental changes and extrapulmonary complications. Annals of Internal Medicine, 63, 829.

Dutton, R. Jr., Nicholas, W., Fisher, C. J., and Renzetti, A. D. Jr. (1959). Blood ammonia in chronic pulmonary emphysema. New England Journal of Medicine, 261, 1369.

Jaikin, A. and Agrest, A. (1969). Cerebrospinal fluid glutamine concentration in patients with chronic hypercapnia. Clinical Science, 36, 11.

Kaplansky, S. Y. and Berezovskaya, N. N. (1956). On the formation of alanine, glutamic and aspartic acids from keto acids and ammonium salts in slices of rat liver. Biochemistry, 21, 115.

Krebs, H. A. (1935). Metabolism of amino-acids; synthesis of glutamine from glutamic acid and ammonia, and enzymatic hydrolysis of glutamine in animal tissues. Biochemical Journal, 29, 1951.

Merwarth, C. R., Sieker, H. O., and Manfredi, F. (1961). Acid-base relations between blood and cerebrospinal fluid in normal subjects and $\stackrel{2}{\mathbb{2}}$ patients with respiratory insufficiency. New England Journal of Medicine, 265, 310.

Miller, G. E. and Rice, J. D. Jr. (1963). Determination of the concentration of ammonia nitrogen in plasma by means of a simple ion exchange method. American Journal of Clinical Pathology, 39, 97.

Mitchell, R. A., Herbert, D. A., and Carman, C. T. (1965). Acid-base constants and temperature coefficients for cerebrospinal fluid. Journal of Applied Physiology, 20, 27.

Posner, J. B. and Plum, F. (1967). Spinal-fluid pH O and neurologic symptoms in systemic acidosis. New England Journal of Medicine, 277, 605. Swanson, A. G., and Plum, F. (1965). Acid-base $D$ balance in cerebrospinal fluid. Archives of 을 Neurology and Psychiatry, 12, 479.

Seligson, D. and Hirahara, K. (1957). The measure- os ment of ammonia in whole blood erythrocytes $N$ and plasma. Journal of Laboratory and Clinical $\mathrm{N}$ Medicine, 49, 962.

and Seligson, H. (1951). Microdiffusion method for the determination of nitrogen liberated as ammonia. Journal of Laboratory and Clinical $\mathbb{\complement}$ Medicine, 38, 324.

Siggaard-Andersen, O., Engel, K., Jørgensen, K., and Astrup, P. (1960). A micro method for determination of $\mathrm{pH}$, carbon dioxide tension, base excess $\mathbb{D}$ and standard biocarbonate in capillary blood. $\frac{\Omega}{(1)}$ Scandinavian Journal of Clinical and Laboratory $\varrho$ Investigation, 12, 172. 
Szam, I., Vass, A., and Wein, I. (1969). Hyperammonemia in cor pulmonale. Cardiologia, 54, 321.

Valero, A., Alroy, G., and Stein, A. (1971). Cerebrospinal fluid glutamine, blood-CSF, acid-base balance and their relation to neurologic symptoms in chronic hypercapnia. Respiration, 28, 137.
Whitehead, T. P. and Whittaker, S. R. F. (1955). A method for determination of glutamine in CSF and the results in hepatic coma. Journal of Clinical Pathology, 8, 81 .

Requests for reprints to: Dr. A. Valero, The Medical Department B, Rambam University Hospital, Haifa, Israel. 